\title{
UAE Neem Extract as a Corrosion Inhibitor for Carbon Steel in HCl Solution
}

\author{
Ayssar Nahlé, Ideisan Abu-Abdoun, Ibrahim Abdel-Rahman, and Maysoon Al-Khayat \\ Department of Chemistry, College of Sciences, University of Sharjah, P.O. Box 27272, Sharjah, UAE \\ Correspondence should be addressed to Ayssar Nahlé, anahle@sharjah.ac.ae \\ Received 3 December 2009; Accepted 9 July 2010 \\ Academic Editor: Vesna B. Mišković-Stanković \\ Copyright ( 2010 Ayssar Nahlé et al. This is an open access article distributed under the Creative Commons Attribution License, \\ which permits unrestricted use, distribution, and reproduction in any medium, provided the original work is properly cited.
}

The effect of aqueous extract of UAE Neem (Azadirachta Indica) on the corrosion inhibition of carbon steel in $1.0 \mathrm{M} \mathrm{HCl}$ solution was investigated electrochemically, and by weight-loss experiments at temperatures ranging from 303 to $343 \mathrm{~K}$. The percentage inhibition increased with the increase of the concentration of the inhibitor. At a concentration of $2.0 \mathrm{~g} / \mathrm{L}$, the percentage inhibition reached about $87 \%$ at room temperature and $80 \%$ at $303 \mathrm{~K}$. The percentage inhibition decreased with the increase of temperature. The thermodynamic parameters for the adsorption of this inhibitor on the metal surface were calculated using the Temkin adsorption isotherm. The aqueous Neem leaves extract was found to be an excellent potential corrosion inhibitor because of the high content of tannin content as well as the presence of a series of complex triterpene glycosides.

\section{Introduction}

The corrosion of metals in many industries, constructions, installations, and civil services such as electricity, water, and sewage supplies is a serious problem. In order to prevent or minimize corrosion, inhibitors are usually used especially in flow cooling systems. Organic, inorganic, or a mixture of both inhibitors can inhibit corrosion by either chemisorption on the metal surface or reacting with metal ions and forming a barrier-type precipitate on its surface [1].

Because of the toxic nature and/or high cost of some chemicals currently in use as inhibitors, it is necessary to develop environmentally acceptable and inexpensive ones. Natural products can be considered as a good source for this purpose. The aqueous extracts from different parts of some plants such as Henna, Lawsonia inermis [1], Rosmarinous officinalis L. [2], Carica papaya [3], cordia latifolia and curcumin [4], date palm, phoenix dactylifera, henna, lawsonia inermis, corn, Zea mays [5], and Nypa Fruticans Wurmb [6] have been found to be good corrosion inhibitors for many metals and alloys. Recently, an excellent review about "natural products as corrosion inhibitors for metals in corrosive media" has been published [7].
No studies have been reported on the aqueous extract of Neem leaves planted in UAE, Azadirachta indica, as corrosion inhibitor used in our present work, in terms of studying both the electrochemical effect and the temperature effect on the corrosion inhibition of carbon steel in $1.0 \mathrm{M} \mathrm{HCl}$ solution. Carbon steel was chosen in our studies since high temperature aggressive acids are widely used in industries in connection to carbon and low alloy steels.

The aim of this work is to study, using potentiodynamic and weight-loss measurements, the effect of temperature on the corrosion inhibition of carbon steel in $1.0 \mathrm{M} \mathrm{HCl}$ solution by the aqueous extract of Neem leaves, and to calculate the thermodynamic parameters. The output of this study is intended to be a cheap and an eco-friendly natural source that can be utilized as a corrosion inhibitor for metals and alloys.

\section{Experimental}

The leaves were collected from 10 years old Neem trees planted on the University of Sharjah premises (Sharjah, United Arab Emirates), dried at room temperature, and stored in dark for later use. 
TABLE 1: The effect of soaking time of Neem leaves in distilled water on the percentage inhibition.

\begin{tabular}{ll}
\hline $\begin{array}{l}\text { Time of soaking neem } \\
\text { leaves in water (hours) }\end{array}$ & Inhibition at $303 \mathrm{~K}(\%)$ \\
\hline 0.17 & 50 \\
0.33 & 55 \\
0.5 & 60 \\
1 & 70 \\
3 & 77 \\
7 & 80 \\
14 & 80 \\
24 & 80 \\
168 & 80 \\
\hline
\end{tabular}

Several extraction procedures were tested. These extraction procedures included extraction by distilled water at $80^{\circ} \mathrm{C}$, extraction by distilled water at room temperature, and extraction by boiling ethanol $\left(78^{\circ} \mathrm{C}\right)$. Preliminary corrosion studies by weight-loss measurements were carried out in order to find the optimal extraction procedure. These preliminary corrosion measurements showed that the aqueous extraction at room temperature was the same or far more efficient than the two other procedures. This extraction procedure was adopted in our current work.

In order to optimize the time of extraction of the Neem, $2.0 \mathrm{~g}$ of the dry Neem leaves were soaked in $60 \mathrm{~mL}$ distilled water at room temperature $\left(20^{\circ} \mathrm{C}\right)$ for various time ranging from 0.17 hours to 168 hours, followed by filtration, then added to an aqueous $\mathrm{HCl}$ solution to make a $1.0 \mathrm{~L}$ solution in $1.0 \mathrm{M} \mathrm{HCl}$. Weight-loss measurements described in (Section 2.2.3) were carried out on steel specimens prepared as shown in (Section 2.2.1) in each extract solution. The percent inhibition was finally calculated according to (2). It was found that 7 hours was the optimal soaking time as shown in Table 1 and Figure 1.

In this work, $2.0 \mathrm{~g}$ of dry Neem leaves were soaked in $60.0 \mathrm{~mL}$ distilled water at room temperature $\left(20^{\circ} \mathrm{C}\right)$ for 7 hours (the optimal time), and then filtered. The filtrate was added to an aqueous $\mathrm{HCl}$ solution to make a $1.0 \mathrm{~L}$ stock solution in $1.0 \mathrm{M} \mathrm{HCl}$. From the stock solution, a series of diluted solutions in $1.0 \mathrm{M} \mathrm{HCl}$ were prepared with concentrations ranging from $2.0 \mathrm{~g} / \mathrm{L}$ to $0.02 \mathrm{~g} / \mathrm{L}$.

\subsection{Electrochemistry}

2.1.1. Electrode Preparation. $5 \mathrm{~mm}$ diameter working electrode was prepared from a $5 \mathrm{~mm}$ diameter carbon steel rod (IS 226 containing $0.18 \% \mathrm{C}, 0.6 \% \mathrm{Mn}$, and $0.35 \%$ Si) supplied by "Reliable Steel Traders", Sharjah, UAE; and mounted, using Araldite epoxy resin, in a glass tube that fits in the electrochemical cell. The working carbon steel electrode was abraded using a series of carborundum papers starting with 600 grades and ending with 1200 grades prior to each experiment. The electrode surface was then polished with $0.3 \mu \mathrm{m}$ alumina on cloth, washed with deionized distilled water, and rinsed with pure ethanol before

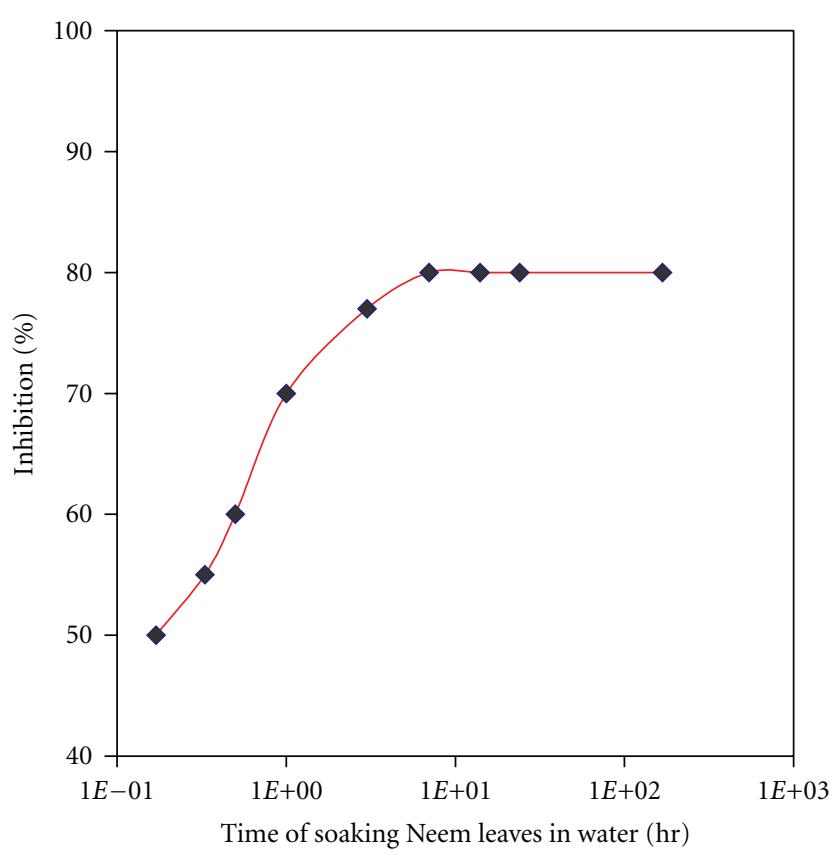

Figure 1: The effect of soaking time of Neem leaves in distilled water on the percentage inhibition.

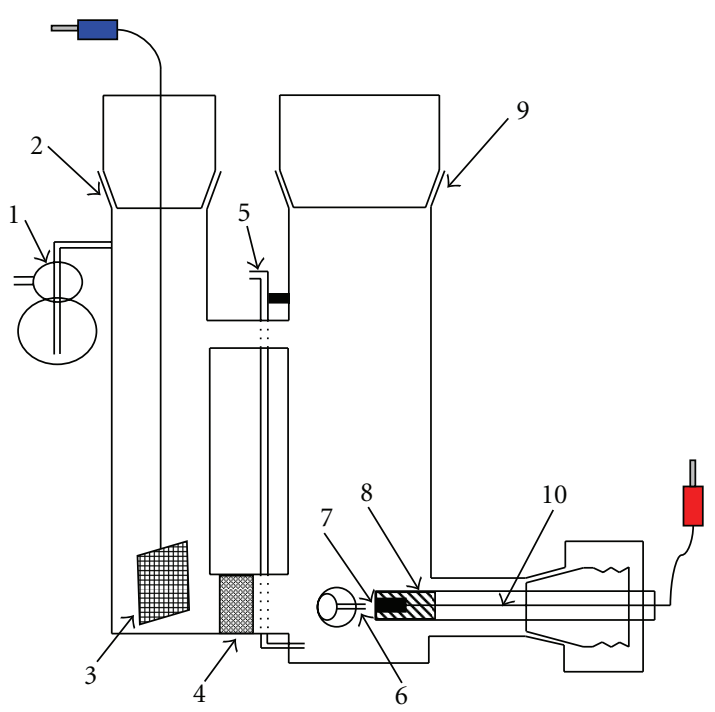

Figure 2: The electrochemical cell. (1) gas bubbler, (2) B 12 glass socket, (3) Platinum gauze (counter electrode), (4) glass frit, (5) inlet for nitrogen gas, (6) luggin capillary (reference electrode), (7) steel rod (working electrode), (8) epoxy resin, (9) B 24 glass socket, (10) copper wire.

it was transferred to the electrochemical cell that contained deaerated fresh electrolyte.

2.1.2. Instrumentation. The same electrochemical glass cell (made in Southampton University, England) used in our previous works [8-13] and described in Figure 2 was here employed. The electrochemical cell consisted of a carbon steel working electrode (WE), a saturated calomel electrode 
(SCE) as a reference electrode (RE), and platinum gauze counter electrode (CE). Prior to each experiment, the electrolyte was deaerated by nitrogen bubbling. The cell design allowed nitrogen to escape into the solution, precluding its collection at the electrode surface that is fitted horizontally.

The counter-electrode compartment was separated from the working-electrode compartment with a glass frit. This way, the working electrode was protected from any substance that may be produced at the counter electrode during the electrochemical reactions. The electrochemical equipment and chemicals used were as follows.

A PC-controlled Sycopel AEW2-1000 electrochemical workstation (supplied from Sycopel Scientific Limited, England) capable of driving currents up to $\pm 1 \mathrm{~A}$ with an output potential across the cell of up to $\pm 10 \mathrm{~V}$.

Analytical-grade hydrochloric acid (Ajax) was used.

2.1.3. Measuring Procedure. Electrochemical corrosion measurements (Tafel plots) were carried out on the carbon steel electrode, prepared as described above, in $1.0 \mathrm{M} \mathrm{HCl}$ and in $1.0 \mathrm{M} \mathrm{HCl}$ containing various concentrations of the aqueous Neem extract. The concentration of the Neem extract ranged from $2.0 \mathrm{~g} / \mathrm{L}$ to $0.2 \mathrm{~g} / \mathrm{L}$.

60 milliliters of the freshly prepared electrolyte was filled in the electrochemical cell. The solution was then deaerated with nitrogen gas; and the working electrode equilibrium potential versus SCE was recorded until it reached a steady state. Finally, the electrode potential was scanned from $-700 \mathrm{mV}$ to $-100 \mathrm{mV}$ versus SCE at a sweep rate of $1 \mathrm{mV} \cdot \mathrm{s}^{-1}$. The data were collected and plotted as logarithm of the absolute value of the current $(\log |I|, \mathrm{mA})$ versus the electrode potential $(E, \mathrm{mV})$ versus SCE. With extreme experimental precautions taken, and with a newly polished electrode and fresh electrolyte, the experiment was repeated for at least three times in order to ensure the reproducibility of the results. Once reproducible plots were obtained, the corrosion currents were then extrapolated from the log $|I|$ (logarithm of current, $\mathrm{mA}$ ) versus electrode potential plots (Tafel plots).

\subsection{Effect of Temperature}

2.2.1. Specimen Preparation. Rectangular specimens $(1 \mathrm{~cm} \times$ $2.3 \mathrm{~cm} \times 0.3 \mathrm{~cm})$ were cut from a $3 \mathrm{~mm}$ thick carbon steel sheet (IS 226 containing $0.18 \%$ C, $0.6 \% \mathrm{Mn}$, and $0.35 \% \mathrm{Si}$ ) supplied by "Reliable Steel Traders", Sharjah, UAE; and used in the weight loss measurements. Close to the upper edge of the specimen, a $2 \mathrm{~mm}$ diameter hole was drilled and served to be hooked with a glass rod for immersion purposes. The specimens were polished with 600 grade emery paper, rinsed with distilled water, degreased with acetone, dried, and finally weighed precisely on an accurate analytical balance prior to each experiment.

2.2.2. Instrumentation. For the weight-loss measurements $[14,15]$, a $250 \mathrm{~mL}$ round bottom flask fitted with a reflux condenser and long glass rod which served to hook and immerse the specimen and in turn immersed in a thermally controlled water bath was used.

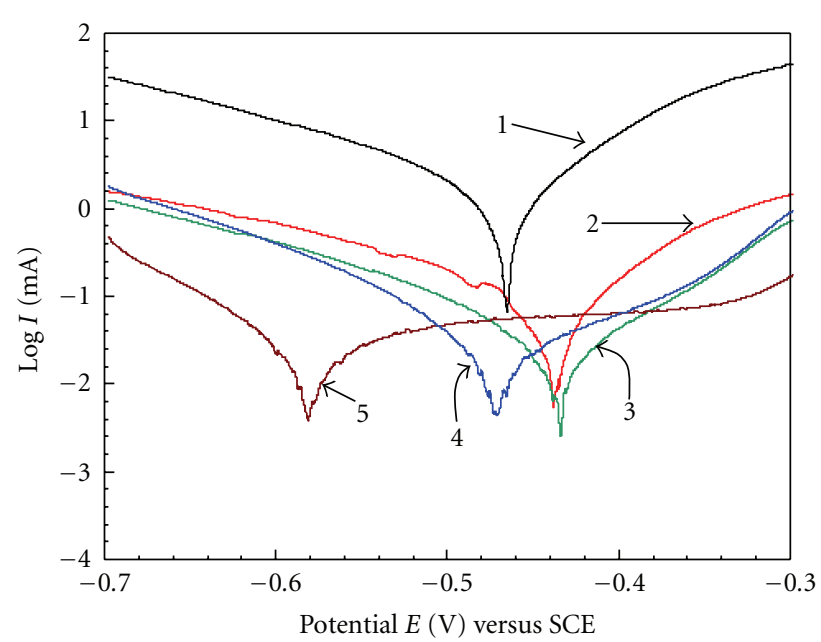

Figure 3: Anodic and cathodic polarization curves of carbon steel in an uninhibited $1.0 \mathrm{M} \mathrm{HCl}$ solution and in $1.0 \mathrm{M} \mathrm{HCl}$ containing various concentrations of the aqueous extract of Neem leaves.(1) $1.0 \mathrm{M} \mathrm{HCl}$; (2) $1.0 \mathrm{M} \mathrm{HCl}+0.20 \mathrm{~g} / \mathrm{L}$ extract; (3) $1.0 \mathrm{M} \mathrm{HCl}+$ $0.50 \mathrm{~g} / \mathrm{L}$ extract; (4) $1.0 \mathrm{M} \mathrm{HCl}+1.00 \mathrm{~g} / \mathrm{L}$ extract; (5) $1.0 \mathrm{M} \mathrm{HCl}$ $+2.00 \mathrm{~g} / \mathrm{L}$ extract.

2.2.3. Measuring Procedure. $100 \mathrm{~mL}$ of $1.0 \mathrm{M} \mathrm{HCl}$ solution either with or without the presence of various concentrations of aqueous Neem extract were transferred in the flask. The flask was then placed in water bath. When the required temperature was reached, the precisely weighed carbon steel specimen hooked with a glass rod was immersed in the solution for exactly six hours. After that time, the sample was removed, rinsed with distilled deionized water, degreased with acetone, dried, and finally weighed precisely on an accurate analytical balance. This procedure was repeated for a variety of inhibitor concentrations ranging from $0.02 \mathrm{~g} / \mathrm{L}$ to $2.00 \mathrm{~g} / \mathrm{L}$; and at temperatures ranging from $303 \mathrm{~K}$ to $343 \mathrm{~K}$.

\section{Results and Discussion}

3.1. Electrochemistry. The anodic and cathodic polarization curves (Tafel plot) of the carbon steel electrode in deaerated $1.0 \mathrm{M} \mathrm{HCl}$ solution with and without the addition of various concentrations of the aqueous Neem extract are shown in Figure 3. The aqueous Neem extract acted as a mixed inhibitor because its presence at all concentrations affected both, the anodic and the cathodic branches of the polarization curves. Furthermore, the polarization curves corresponding to all concentrations of the aqueous Neem extract were all almost at equal distance from that recorded with uninhibited 1.0 M HCl. The corrosion current of carbon steel electrode in each solution was determined by locating the intersections of extrapolated tangents of the anodic and cathodic curves of the Tafel plot at the corrosion potential $\left(E_{\text {rest }}\right)$. Values of associated electrochemical parameters and corresponding percent inhibition are given in Table 2 . The corrosion current was found to decrease with the increase of the concentration of the inhibitor as shown in Table 2. In the absence of inhibitor $(1.0 \mathrm{M} \mathrm{HCl})$, the corrosion current was 
TABLE 2: Tafel corrosion currents and percentage inhibitions of the aqueous extract of Neem leaves at various concentrations in $1.0 \mathrm{M} \mathrm{HCl}$ at room temperature.

\begin{tabular}{|c|c|c|c|c|c|}
\hline & $1.0 \mathrm{M} \mathrm{HCl}$ & $\begin{array}{l}1.0 \mathrm{M} \mathrm{HCl}+ \\
0.20 \mathrm{~g} / \mathrm{LExtract} \\
\text { of Neem }\end{array}$ & $\begin{array}{l}1.0 \mathrm{M} \mathrm{HCl}+ \\
0.50 \mathrm{~g} / \mathrm{LExtract} \\
\text { of Neem }\end{array}$ & $\begin{array}{l}1.0 \mathrm{M} \mathrm{HCl}+ \\
1.00 \mathrm{~g} / \mathrm{LExtract} \\
\text { of Neem }\end{array}$ & $\begin{array}{l}1.0 \mathrm{M} \mathrm{HCl}+ \\
2.00 \mathrm{~g} / \mathrm{LExtract} \\
\text { of Neem }\end{array}$ \\
\hline$E_{\text {rest }} / \mathrm{V}$ versus SCE & -0.465 & -0.438 & -0.433 & -0.472 & -0.583 \\
\hline$b_{a} /(\mathrm{mV} / \mathrm{dec})$. & 57.5 & 61.1 & 94.5 & 112.0 & 143.9 \\
\hline$b_{a} /(\mathrm{mV} /$ dec. $)$ & 63.8 & 56.1 & 87.7 & 77.2 & 76.1 \\
\hline$I$ “corrosion" $/ \mathrm{mA}$ & 0.76 & 0.237 & 0.169 & 0.151 & 0.101 \\
\hline PercentInhibition & - & 68.82 & 77.76 & 80.13 & 86.84 \\
\hline
\end{tabular}

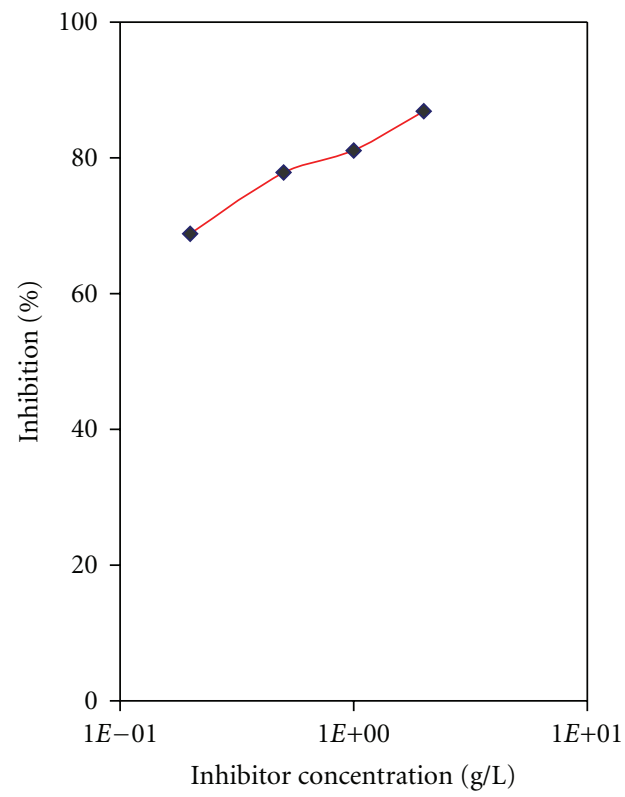

Figure 4: Percentage inhibition of different concentrations of the aqueous extract of Neem leaves on carbon steel surface in $1.0 \mathrm{M}$ $\mathrm{HCl}$ solution at room temperature based on anodic and cathodic polarization curves.

$0.76 \mathrm{~mA}$; and dropped to $0.101 \mathrm{~mA}$ when the concentration of aqueous Neem leaves extract reached $2.0 \mathrm{~g} / \mathrm{L}$ in $1.0 \mathrm{M} \mathrm{HCl}$ (Table 2).

The values of percentage inhibition of aqueous Neem extract at various concentrations in $1.0 \mathrm{M} \mathrm{HCl}$ were calculated according to (1), and are shown in Table 2:

$$
\text { Percentage Inhibition }=\frac{\left(I_{\text {Corr. }}\right)_{\text {Uninh. }}-\left(I_{\text {Corr. }}\right)_{\text {Inh. }}}{\left(I_{\text {Corr. }}\right)_{\text {Uninh. }}} \times 100 \text {, }
$$

where $\left(I_{\text {Corr. }}\right)_{\text {Uninh. }}=$ Corrosion current in the uninhibited solution, and $\left(I_{\text {Corr. }}\right)_{\text {Inh. }}=$ Corrosion current in inhibited solution.

The plot of the percentage inhibition versus the concentration of the aqueous Neem extract in $1.0 \mathrm{M} \mathrm{HCl}$ is shown in Figure 4. This figure shows that the percentage inhibition has steeply increased from about $69 \%$ with $0.20 \mathrm{~g} / \mathrm{L}$ inhibitor to about $87 \%$ with $2.0 \mathrm{~g} / \mathrm{L}$ inhibitor.
There are many factors affecting the corrosion inhibition efficiency by organic compounds such as the number and types of adsorbing groups as well as their molecular size, molecular structure, and mode of interaction with the corroding metal surface. These molecules have the ability to inhibit corrosion either by chemisorption or physisorption on the metal surface. The molecules that physisorbed reduce corrosion by shifting the cathodic reaction at the sides where they attached, while the chemisorbed ones that attached at the anodic areas retard the reactivity of these areas towards corrosion. Neem is bitter in taste due to the high content of tannins and a series of complex compounds called "triterpenes" or more specifically "limonoids". One of the most important triterpenes is azadirachtin. Nearly 100 protolimonoids, limonoids or tetranortriterpenoids, pentanortriterpenoids, exanortriterpenoids, and some ponterpenoid constituents have been isolated from various parts of the Neem tree; still more are being isolated. As tannins contain polyphenolic moieties and these moieties have the ability to form tanninate salts with ferric ions, the corrosion inhibition of tannins is due to the formation of a highly cross-lined network of ferric tanninate salts that protect the metal surface. In the same way, triterpenes have some functional groups such as $(\mathrm{OH}, \mathrm{C}=\mathrm{O}, \mathrm{C}=\mathrm{C})$ that can interact with the metal surface and protect it from the attack of hydronium $\left(\mathrm{H}_{3} \mathrm{O}^{+}\right)$ions.

When the electrode was pulled out from the $1.0 \mathrm{M} \mathrm{HCl}$ containing an aqueous extract of $2.0 \mathrm{~g} / \mathrm{L}$ of Neem leaves (at the end of the experiment), the carbon steel surface was more clean (about $87 \%$ inhibition) compared with the experiment with concentration of $0.20 \mathrm{~g} / \mathrm{L}$ in $1.0 \mathrm{M} \mathrm{HCl}$ (about $69 \%$ inhibition).

The high inhibition efficiency may be attributed to the presence of tannins, triterpenes, and many other organic compounds that have been extracted by only soaking the dry Neem leaves in distilled water.

\subsection{Effect of Temperature}

Weight-loss corrosion tests were carried out on the carbon steel immersed in $1.0 \mathrm{M} \mathrm{HCl}$ in the absence or presence of aqueous Neem extract over a period of 6 hours. Table 3 represents the corrosion rate $\left[\mathrm{mg} \cdot \mathrm{cm}^{-2} \cdot \mathrm{h}^{-1}\right]$ and the percentage efficiency for Neem inhibitor with concentrations varying from $0.02 \mathrm{~g} / \mathrm{L}$ to $2.00 \mathrm{~g} / \mathrm{L}$ at $303,313,323,333$, and 
TABLE 3: The Effect of concentration of the aqueous extract of Neem leaves on the corrosion rate $\left(\mathrm{mg} \cdot \mathrm{cm}^{-2} \cdot \mathrm{h}^{-1}\right)$ and percentage efficiency of carbon steel in $1.0 \mathrm{M} \mathrm{HCl}$ at various temperatures.

Temperaure e/K

$\begin{array}{llll}343 & 333 & 323 & 313\end{array}$

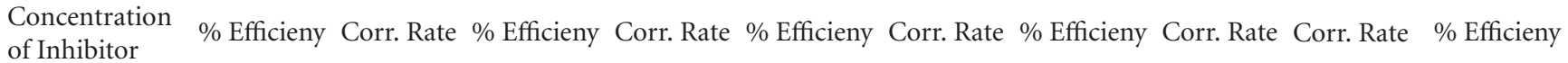

\begin{tabular}{lcccccccccc}
\hline $\begin{array}{l}1.0 \mathrm{M} \mathrm{HCl} \\
1.0 \mathrm{M} \mathrm{HCl}+ \\
0.02 \mathrm{~g} / \mathrm{L}\end{array}$ & 0.961 & - & 1.394 & - & 4.671 & - & 12.225 & - & 26.280 \\
$\begin{array}{l}1.0 \mathrm{M} \mathrm{HCl}+ \\
0.20 \mathrm{~g} / \mathrm{L}\end{array}$ & 0.548 & 43 & 0.920 & 34 & 3.643 & 22 & 11.247 & 8 & 32.324 & -23 \\
$\begin{array}{l}1.0 \mathrm{M} \mathrm{HCl}+ \\
0.50 \mathrm{~g} / \mathrm{L}\end{array}$ & 0.250 & 74 & 0.544 & 61 & 2.382 & 49 & 9.169 & 25 & 27.594 & -18 \\
$\begin{array}{l}1.0 \mathrm{M} \mathrm{HCl}+ \\
1.00 \mathrm{~g} / \mathrm{L}\end{array}$ & 0.221 & 77 & 0.516 & 63 & 2.055 & 56 & 7.964 & 35 & 25.229 \\
$\begin{array}{l}1.0 \mathrm{M} \mathrm{HCl}+ \\
2.00 \mathrm{~g} / \mathrm{L}\end{array}$ & 0.192 & 80 & 0.446 & 68 & 1.822 & 61 & 7.335 & 40 & 24.178
\end{tabular}

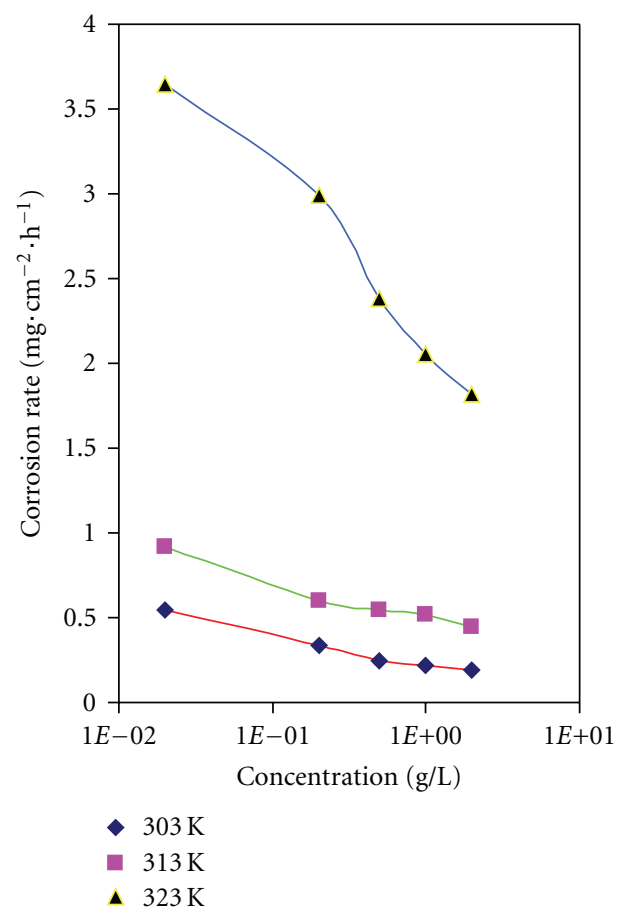

FIGURE 5: Effect of concentration of the aqueous extract of Neem leaves on the corrosion rate $\left(\mathrm{mg} \cdot \mathrm{cm}^{-2} \cdot \mathrm{h}^{-1}\right)$ of carbon steel in $1.0 \mathrm{M}$ $\mathrm{HCl}$ at various temperatures.

$343 \mathrm{~K}$, respectively. The percentage efficiency was calculated according to (2):

$$
\% \text { Inhibition }=\frac{W_{\text {Uninh. }}-W_{\text {Inh. }}}{W_{\text {Uninh. }}} \times 100,
$$

where $W_{\text {Uninh. }}=$ corrosion rate without inhibitor; and $W_{\text {Inh. }}=$ corrosion rate with inhibitor.

The corrosion rate of the carbon steel in $1.0 \mathrm{M} \mathrm{HCl}$ as a function of various concentrations of aqueous extract of Neem leaves at temperatures between 303 and $343 \mathrm{~K}$ were

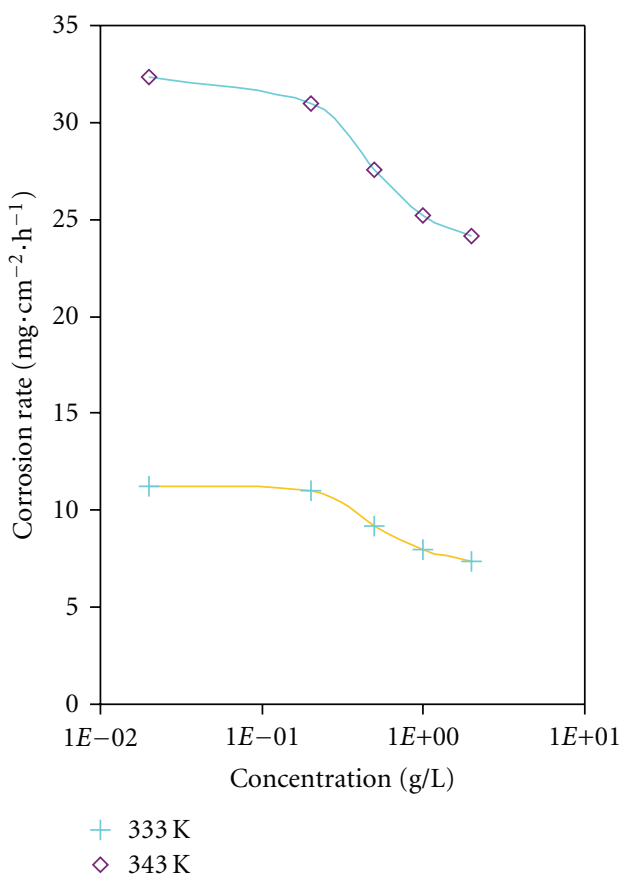

Figure 6: Effect of concentration of the aqueous extract of Neem leaves on the corrosion rate $\left(\mathrm{mg} \cdot \mathrm{cm}^{-2} \cdot \mathrm{h}^{-1}\right)$ of carbon steel in $1.0 \mathrm{M}$ $\mathrm{HCl}$ at various temperatures.

shown in Figures 5 and 6 . It was obviously noticed that the corrosion rate dropped rapidly at lower concentrations of the extract Neem than at higher ones at $303 \mathrm{~K}$ and $313 \mathrm{~K}$, while the situation was the opposite at $323 \mathrm{~K}$ and $333 \mathrm{~K}$. At $343 \mathrm{~K}$, there was no inhibition at all at low concentrations and instead, acceleration in the rate of corrosion was noticed. This could be due to the presence of the ions in the Neem leaves extract (extracted with water), and because at this elevated temperature the adsorption of the inhibitor (at low concentration) was low, the dissolved ions had high influence on the increase of the corrosion rate in addition to the $\mathrm{HCl}$ 
TABLE 4: The data obtained from the weight loss measurements for Arrhenius Equation: $(I / T)$ against Ln (Corrosion Rate).

\begin{tabular}{ccccccc}
\hline \multicolumn{5}{c}{$\mathrm{Ln}($ Corrosion Rate $) / \mathrm{mg} \cdot \mathrm{cm}^{-2} \cdot \mathrm{h}^{-1}$} \\
$(1 / T) \times 10^{3} / \mathrm{K}^{-1}$ & $1.0 \mathrm{M} \mathrm{HCl}$ & $1.0 \mathrm{M} \mathrm{HCl}+0.02 \mathrm{~g} / \mathrm{L}$ & $1.0 \mathrm{M} \mathrm{HCl}+0.20 \mathrm{~g} / \mathrm{L}$ & $1.0 \mathrm{M} \mathrm{HCl}+0.50 \mathrm{~g} / \mathrm{L}$ & $1.0 \mathrm{M} \mathrm{HCl}+1.00 \mathrm{~g} / \mathrm{L}$ & $1.0 \mathrm{M} \mathrm{HCl}+2.00 \mathrm{~g} / \mathrm{L}$ \\
\hline 3.30 & -0.03978 & -0.60148 & -1.09064 & -1.38629 & -1.50959 & -1.65026 \\
3.19 & 0.33218 & -0.08338 & -0.51083 & -0.59059 & -0.66165 & -0.80744 \\
3.10 & 1.54137 & 1.29281 & 1.09494 & 0.86794 & 0.72028 & 0.59993 \\
3.00 & 2.50348 & 2.4201 & 2.39817 & 2.21583 & 2.07493 & 3.99266 \\
2.92 & 3.26881 & 3.47581 & 3.43431 & 3.3176 & 3.22799 & 3.18544 \\
\hline
\end{tabular}

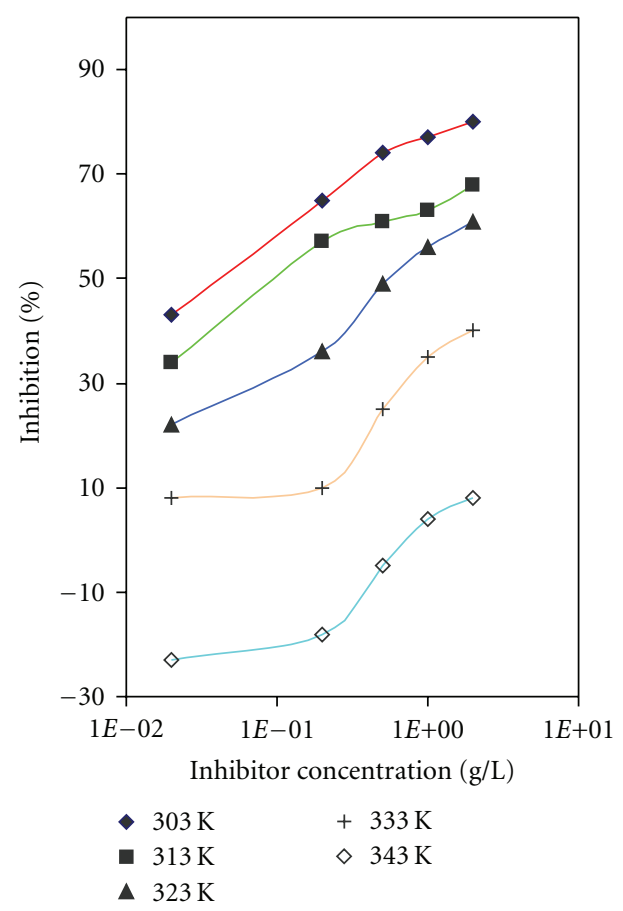

Figure 7: Effect of concentration of the aqueous extract of Neem leaves on the percent inhibition of carbon steel in $1.0 \mathrm{M} \mathrm{HCl}$ at various temperatures.

solution. When the concentration of the extract increased, more inhibitor seemed to get adsorbed on the metal surface, which in turn caused less effect of dissolved ions on the corrosion rate.

The relative decrease in the corrosion rate was more significant at lower temperatures than at higher ones as shown in Figures 5 and 6. This means that the rate of corrosion decreased more significantly at lower temperatures.

The plots of the percentage inhibition as a function of the concentration of the aqueous extract of Neem leaves at temperatures ranging from $303 \mathrm{~K}$ to $343 \mathrm{~K}$ were shown in Figure 7. Similar to the rate of corrosion in Figures 5 and 6 , the inhibition was so obvious and more effective at low temperatures than at higher ones, and even a catalysis effect (negative inhibition values) was noticed at $343 \mathrm{~K}$ and concentrations of equal or less than $0.50 \mathrm{~g} / \mathrm{L}$.

According to Arrhenius Equation (3), the values of natural logarithms of the rate of corrosion (ln Rate of corrosion) and the values of the reciprocal of the temperature

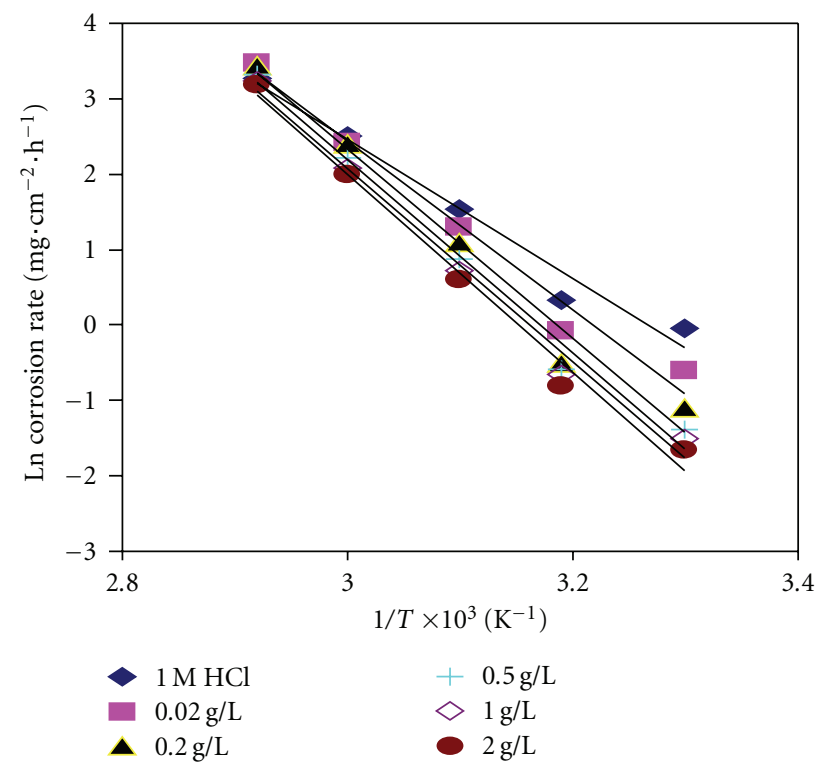

Figure 8: The Arrhenius plots of the corrosion rate of carbon steel in $1.0 \mathrm{M} \mathrm{HCl}$ solution with and without the presence of various concentrations of the aqueous extract of Neem leaves.

in $\mathrm{K}^{-1}(1 / T)$ were tabulated in Table 4:

$$
\ln \text { rate }=-\frac{E_{a}}{R T}+\text { constant, }
$$

where $E_{a}=$ activation energy $\left[\mathrm{kcal} \cdot \mathrm{mol}^{-1}\right], R=$ gas constant $\left[\mathrm{kcal} \cdot \mathrm{mol}^{-1}\right], T=$ absolute temperature $[\mathrm{K}]$, and const. $=$ constant

The Arrhenius plots of the corrosion of carbon steel in $1.0 \mathrm{M} \mathrm{HCl}$ solution, (ln corrosion rate as a function of $1 / T$ ) with or without the presence of the aqueous extract of Neem leaves at concentrations ranging from $0.02 \mathrm{~g} / \mathrm{L}$ to $2.0 \mathrm{~g} / \mathrm{L}$ are plotted in Figure 8. From this figure, the slope $\left(-E_{a} / R\right)$ of each line was determined and used to calculate the activation energy according to (3), with $R=1.987 \times 10^{-3} \mathrm{kcal} \cdot \mathrm{mol}^{-1}$. It is clearly noticed that as the concentration of the extract increases, the activation energy for the corrosion of carbon steel in $1.0 \mathrm{M} \mathrm{HCl}$ is also increase $\left(18.27 \mathrm{kcal} \cdot \mathrm{mol}^{-1}\right.$ in $1.0 \mathrm{M}$ $\mathrm{HCl}$ without inhibitor to $25.96 \mathrm{kcal} \cdot \mathrm{mol}^{-1}$ with an aqueous extract of Neem leaves of $2.0 \mathrm{~g} / \mathrm{L}$ in $1.0 \mathrm{M} \mathrm{HCl}$ ), (Table 5).

The values of the surface coverage of various concentrations of the aqueous Neem leaves extract (from $0.02 \mathrm{~g} / \mathrm{L}$ to $2.0 \mathrm{~g} / \mathrm{L}$ ) on carbon steel surface at various temperatures are 
TABLE 5: The activation energy $\left(E_{a}\right)$ for the corrosion of carbon steel in $1.0 \mathrm{M} \mathrm{HCl}$ with and without the aqueous extract of Neem leaves at various concentrations.

\begin{tabular}{lccccc}
\hline \multirow{2}{*}{ System } & \multicolumn{5}{c}{ Activation Energy, $E_{a}\left(\mathrm{kcal} \cdot \mathrm{mol}^{-1}\right)$} \\
& $2.00 \mathrm{~g} / \mathrm{L}$ & $1.00 \mathrm{~g} / \mathrm{L}$ & $0.50 \mathrm{~g} / \mathrm{L}$ & $0.20 \mathrm{~g} / \mathrm{L}$ & $0.02 \mathrm{~g} / \mathrm{L}$ \\
\hline $1.0 \mathrm{M} \mathrm{HCl}$ & 18.27 & 18.27 & 18.27 & 18.27 & 18.27 \\
$1.0 \mathrm{M} \mathrm{HCl}+$ & & & & & \\
$\begin{array}{l}\text { The Aqueous } \\
\text { Extract of }\end{array}$ & 25.96 & 25.42 & 25.43 & 24.88 & 22.15 \\
Neem Leaves & & & & & \\
\hline
\end{tabular}

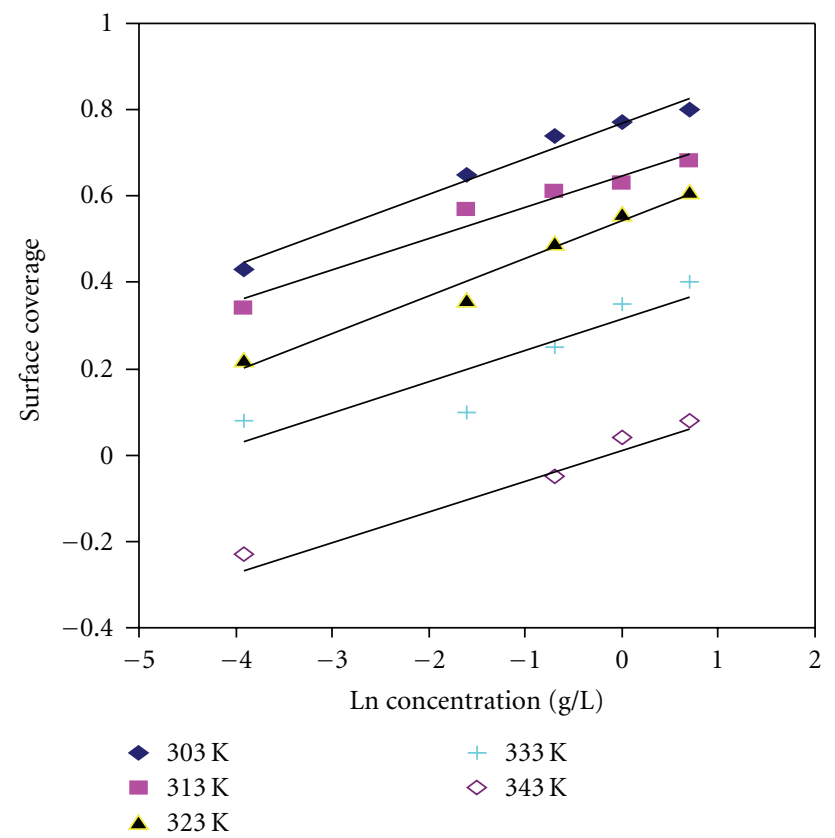

Figure 9: Effect of concentration of the aqueous extract of Neem leaves on the surface coverage of carbon steel in $1.0 \mathrm{M} \mathrm{HCl}$ at various temperatures.

tabulated in Table 6. These values were extracted from the corresponding percentage efficiency values reported earlier in Table 3. The plot of the values of surface coverage, $\theta$, against the natural logarithm of the concentration of Neem leaves aqueous extract; $\ln C$, for carbon steel at various inhibitor temperatures is shown in Figure 9. After examining these data and adjusting them to different theoretical adsorption isotherms, it was concluded that the inhibitor was adsorbed on the carbon steel surface according to Temkin Adsorption Isotherm:

$$
-2 a \theta=\ln K C
$$

where $a=$ molecular interaction constant, $\theta=$ degree of coverage, $K=$ equilibrium constant for the adsorption reaction, and $C=$ concentration of the inhibitor.

The equilibrium constant for the adsorption reaction, $K$, is related to the standard free energy of adsorption via (5) [16]:

$$
K=\frac{1}{55.5} \exp \left(-\frac{\Delta G}{R T}\right)
$$

Where: $K=$ equilibrium constant for the adsorption reaction, $55.5=$ concentration of water $\left[\mathrm{mol} \cdot \mathrm{L}^{-1}\right], \Delta G=$ standard free energy $\left[\mathrm{kcal} \cdot \mathrm{mol}^{-1}\right], R=$ gas constant $\left[\mathrm{kcal} \cdot \mathrm{mol}^{-1}\right]$, and $T=$ absolute temperature $[\mathrm{K}]$.

According to (4), the straight lines shown in Figure 9 will have the following slopes and intercepts:

$$
\begin{aligned}
\text { Slope } & =-\frac{1}{2 a}, \\
\text { Intercept } & =-\frac{1}{2 a} \ln K .
\end{aligned}
$$

Combination of (6) and (7) leads to the following relationships:

$$
\begin{gathered}
\text { Intercept }=(\text { Slope })(\ln K), \\
K=e^{(\text {Intercept/Slope })} .
\end{gathered}
$$

Using (9), the equilibrium constant for the adsorption reaction, $K$, was calculated.

The free energy of adsorption of the inhibitor, $\Delta G$, was calculated using (5) at various temperatures (303 K to $343 \mathrm{~K}$ ) as shown in Table 7.

The enthalpy of adsorption, $\Delta H$, for the inhibitor was calculated from the following and is shown in Table 8:

$$
\Delta H=E_{a}-R T \text {. }
$$

The entropy, $\Delta S$, was calculated at various temperatures for the inhibitor using the following and is shown in Table 9:

$$
\Delta G=\Delta H-T \Delta S
$$

The activation energy $\left(E_{a}\right)$ for the corrosion of carbon steel in the presence of the aqueous extract of neem leaves at all concentrations $(0.02 \mathrm{~g} / \mathrm{L}$ to $2.0 \mathrm{~g} / \mathrm{L})$ are higher compared to the activation energy in the absence of the extract $\left(25.96 \mathrm{kcal} \cdot \mathrm{mol}^{-1}\right.$ with the extract of $2.0 \mathrm{~g} / \mathrm{L}$ in $1.0 \mathrm{M}$ $\mathrm{HCl}$ compared with $18.27 \mathrm{kcal} \cdot \mathrm{mol}^{-1}$ in $1.0 \mathrm{M} \mathrm{HCl}$ without extract). This can be attributed to the fact that higher values of $E_{a}$ in the presence of inhibitor compared to its absence are generally consistent with a physisorption, while unchanged or lower values of $E_{a}$ in inhibited solution suggest charge sharing or transfer from the organic inhibitor to the metal surface to form coordinate covalent bonds (chemisorption).

The increase in the activation energies for the corrosion is attributed to a decrease in the adsorption of the inhibitor on the metal surface as the temperature increased, and subsequently, an increase in the corrosion rate will result due to the greater exposed area of the metal surface to the acid. At temperatures as high as $343 \mathrm{~K}$ and concentrations of extract equal or lower than $0.50 \mathrm{~g} / \mathrm{L}$ an acceleration of corrosion of carbon steel was occurred.

The thermodynamic data obtained in the presence of the Neem extract at various temperatures were tabulated in Tables 7 to 9. These thermodynamic quantities represent the algebraic sum of the values for adsorption and desorption. The negative value of $\Delta G$ indicates the spontaneous adsorption of inhibitor on the surface of the carbon steel. 
TABle 6: The Effect of concentration of the aqueous extract of Neem leaves on surface coverage for carbon steel in $1.0 \mathrm{M} \mathrm{HCl}$ at various temperatures.

\begin{tabular}{|c|c|c|c|c|c|}
\hline \multirow[b]{3}{*}{$\begin{array}{l}\text { Concentration } \\
\text { of Inhibitor }\end{array}$} & \multicolumn{3}{|c|}{ Temperature/K } & \multirow[b]{2}{*}{333} & \multirow[b]{2}{*}{343} \\
\hline & 303 & 313 & 323 & & \\
\hline & Surface Coverage $\theta$ & Surface Coverage $\theta$ & Surface Coverage $\theta$ & Surface Coverage $\theta$ & Surface Coverage $\theta$ \\
\hline $\begin{array}{l}1.0 \mathrm{M} \mathrm{HCl}+ \\
0.02 \mathrm{~g} / \mathrm{L}\end{array}$ & 0.43 & 0.34 & 0.22 & 0.08 & -0.23 \\
\hline $\begin{array}{l}1.0 \mathrm{M} \mathrm{HCl}+ \\
0.20 \mathrm{~g} / \mathrm{L}\end{array}$ & 0.65 & 0.57 & 0.36 & 0.10 & -0.18 \\
\hline $\begin{array}{l}1.0 \mathrm{M} \mathrm{HCl}+ \\
0.50 \mathrm{~g} / \mathrm{L}\end{array}$ & 0.74 & 0.61 & 0.49 & 0.25 & -0.05 \\
\hline $\begin{array}{l}1.0 \mathrm{M} \mathrm{HCl}+ \\
1.00 \mathrm{~g} / \mathrm{L}\end{array}$ & 0.77 & 0.63 & 0.56 & 0.35 & 0.04 \\
\hline $\begin{array}{l}1.0 \mathrm{M} \mathrm{HCl}+ \\
2.00 \mathrm{~g} / \mathrm{L}\end{array}$ & 0.80 & 0.68 & 0.61 & 0.40 & 0.08 \\
\hline
\end{tabular}

TABLE 7: The Free energy of adsorption $\left(\Delta G_{\text {ads }}\right)$ for carbon steel in $1.0 \mathrm{M} \mathrm{HCl}$ in the presence of the aqueous extract of Neem leaves at various temperatures $(303 \mathrm{~K}-343 \mathrm{~K})$.

\begin{tabular}{ccccc}
\hline & \multicolumn{4}{c}{$\Delta G, \mathrm{kcal} \cdot \mathrm{mol}^{-1}$} \\
$303 \mathrm{~K}$ & $313 \mathrm{~K}$ & $323 \mathrm{~K}$ & $333 \mathrm{~K}$ & $343 \mathrm{~K}$ \\
\hline-8.01 & -8.04 & -6.58 & -5.52 & -2.84 \\
\hline
\end{tabular}

TABLE 8: The enthalpy of adsorption $(\Delta H)$ for carbon steel in $1.0 \mathrm{M}$ $\mathrm{HCl}$ in the presence of the aqueous extract of $(2.0 \mathrm{~g} / \mathrm{L})$ Neem leaves at various temperatures $(303 \mathrm{~K}-343 \mathrm{~K})$.

\begin{tabular}{lcccc}
\hline \multicolumn{5}{c}{$\Delta H, \mathrm{kcal} \cdot \mathrm{mol}^{-1}$} \\
$303 \mathrm{~K}$ & $313 \mathrm{~K}$ & $323 \mathrm{~K}$ & $333 \mathrm{~K}$ & $343 \mathrm{~K}$ \\
\hline 25.36 & 25.34 & 25.32 & 25.30 & 25.28 \\
\hline
\end{tabular}

TABLE 9: The change in entropy $(\Delta S)$ for carbon steel in $1.0 \mathrm{M} \mathrm{HCl}$ in the presence of the aqueous extract of $(2.0 \mathrm{~g} / \mathrm{L})$ Neem leaves at various temperatures ( $303 \mathrm{~K}-343 \mathrm{~K})$.

\begin{tabular}{lcccc}
\hline & \multicolumn{4}{c}{$\Delta S, \mathrm{kcal} \cdot \mathrm{K}^{-1} \cdot \mathrm{mol}^{-1}$} \\
$303 \mathrm{~K}$ & $313 \mathrm{~K}$ & $323 \mathrm{~K}$ & $333 \mathrm{~K}$ & $343 \mathrm{~K}$ \\
\hline 0.110 & 0.107 & 0.0988 & 0.0926 & 0.0820 \\
\hline
\end{tabular}

The free energy, $\Delta G$, increases from about $-8 \mathrm{kcal} \cdot \mathrm{mol}^{-1}$ at $303 \mathrm{~K}$ to about $-3 \mathrm{kcal} \cdot \mathrm{mol}^{-1}$ at $343 \mathrm{~K}$. The adsorption process is believed to be exothermic and associated with a decrease in entropy $(\Delta S)$ of solute, while the opposite is true for the solvent [17]. The gain in entropy which accompanies the substitutional adsorption process is attributed to the increase in the solvent entropy (Table 9). This agrees with the general suggestion that the absolute values of free energy, $|\Delta G|$, increase with the increase of inhibition efficiency [18$20]$ as the adsorption of organic compound is accompanied by desorption of water molecules off the surface.

The high inhibition efficiency may be attributed to the presence of tannins, triterpenes, and many other organic compounds that have been extracted by only soaking the dry Neem leaves in distilled water. This inhibition may be also due to synergistic interactions between the adsorbed compounds.

These results agree with Fouda et al. [21, 22] who suggested that the inhibition efficiency of organic compounds depends on many factors including their charge density, number of adsorption sites, heat of hydrogenation, mode of interaction with the metal surface, and formation of metallic complexes.

\section{Conclusions}

The aqueous Neem leaves extract was found to be a highly efficient inhibitor for carbon steel in $1.0 \mathrm{M} \mathrm{HCl}$ solution, reaching about $87 \%$ at $2.0 \mathrm{~g} / \mathrm{L}$ and room temperature, a concentration considered to be very moderate. Even at one half of this of this concentration, $1.0 \mathrm{~g} / \mathrm{L}$, an inhibition of about $80 \%$ was obtained at room temperature.

The rate of corrosion of the carbon steel in $1.0 \mathrm{M} \mathrm{HCl}$ is a function of the concentration of the neem extract. This rate decreased as the concentration of the Neem extract is increased.

The percentage of inhibition in the presence of this inhibitor was decreased with temperature which indicates that physical adsorption was the predominant inhibition mechanism because the quantity of adsorbed inhibitor decreases with increasing temperature.

The aqueous Neem leaves extract is an excellent, green, eco-friendly, and very cheap corrosion inhibitor for carbon steel in $1.0 \mathrm{M} \mathrm{HCl}$ solution, so it can be used to replace toxic and highly cost chemicals.

\section{Acknowledgments}

The authors would like to thank the "College of Graduate Studies and Research" at the University of Sharjah for financially supporting this research project as well as their research group entitled: "Corrosion Prevention \& Control." 


\section{References}

[1] H. Al-Sehaibani, "Evaluation of extracts of Henna leaves as environmentally friendly corrosion inhibitors for metals," Materialwissenschaft und Werkstofftechnik, vol. 31, no. 12, pp. 1060-1063, 2000.

[2] M. Kliškić, J. Radošević, S. Gudić, and V. Katalinić, "Aqueous extract of Rosmarinus officinalis $\mathrm{L}$. as inhibitor of $\mathrm{Al}-\mathrm{Mg}$ alloy corrosion in chloride solution," Journal of Applied Electrochemistry, vol. 30, no. 7, pp. 823-830, 2000.

[3] P. C. Okafor and E. E. Ebenso, "Inhibitive action of Carica papaya extracts on the corrosion of mild steel in acidic media and their adsorption characteristics," Pigment and Resin Technology, vol. 36, no. 3, pp. 134-140, 2007.

[4] I. H. Farooqi, A. Hussain, M. A. Quraishi, and P. A. Saini, "Study of low cost eco-friendly compounds as corrosion inhibitors for cooling systems," Anti-Corrosion Methods and Materials, vol. 46, no. 5, pp. 328-331, 1999.

[5] H. H. Rehan, "Corrosion control by water-soluble extracts from leaves of economic plants," Materialwissenschaft und Werkstofftechnik, vol. 34, no. 2, pp. 232-237, 2003.

[6] K. O. Orubite and N. C. Oforka, "Inhibition of the corrosion of mild steel in hydrochloric acid solutions by the extracts of leaves of Nypa fruticans Wurmb," Materials Letters, vol. 58, no. 11, pp. 1768-1772, 2004.

[7] P. B. Raja and M. G. Sethuraman, "Atropine sulphate as corrosion inhibitor for mild steel in sulphuric acid medium," Materials Letters, vol. 62, no. 10-11, pp. 1602-1604, 2008.

[8] A. Nahlé and F. C. Walsh, "Electrochemical studies of two corrosion inhibitors for iron in $\mathrm{HCl}$ : cetyltrimethyl ammonium bromide and tetraphenyl phosphonium chloride," Corrosion Prevention and Control, vol. 42, no. 2, pp. 30-34, 1995.

[9] A. H. Nahlé, "Electrochemical studies of corrosion inhibition of a series of quaternary ammonium salts on iron in $\mathrm{HCl}$ solution," Corrosion Prevention and Control, vol. 44, no. 4, pp. 99-105, 1997.

[10] A. H. Nahlé, "Inhibition of iron in $\mathrm{HCl}$ using benzyl trimethyland triethyl-ammonium chlorides," Corrosion Prevention and Control, vol. 45, no. 4, pp. 124-130, 1998.

[11] A. Nahlé, "Effect of triethanolamine on the electrochemical dissolution of solder in $\mathrm{NaOH}$ solution," Bulletin of Electrochemistry, vol. 18, no. 3, pp. 105-110, 2002.

[12] A. Nahlé, I. Abu-Abdoun, and I. Abdel-Rahman, "Electrochemical studies of the effect of trans-4-hydroxy-4'-stilbazole on the corrosion inhibition of mild steel in $\mathrm{HCl}$ solution," Anti-Corrosion Methods and Materials, vol. 54, no. 4, pp. 244 248, 2007.

[13] A. Nahlé, I. Abu-Abdoun, and I. Abdel-Rahman, "Corrosion inhibition of (Anthraquinone-2-ylmethyl) triphenyl phosphonium bromide on mild steel in $\mathrm{HCl}$ solution," Bulletin of Electrochemistry, vol. 23, pp. 201-209, 2007.

[14] A. Nahlé, "Effect of temperature on the corrosion inhibition of carbon steel in $\mathrm{HCl}$ solutions," Bulletin of Electrochemistry, vol. 17, no. 5, pp. 221-226, 2001.

[15] A. Nahlé, "Inhibition of corrosion of iron in $\mathrm{HCl}$ solution by semicarbazides and thiosemicarbazides," Bulletin of Electrochemistry, vol. 21, no. 6, pp. 275-281, 2005.

[16] B. B. Damaskin, O. A. Pietrij, and W. W. Batrokov, Adsorpcja Organiczeskich Sojedinienij na elektrodach, Moskva, Russia, 1968.

[17] S. H. Sanad, A. A. Ismail, and A. A. El-Meligi, "The effect of temperature on the corrosion and corrosion inhibition of steel alloys in hydrochloric acid solutions," Bulletin of Electrochemistry, vol. 11, no. 10, pp. 462-469, 1995.
[18] B. G. Ateya, B. E. El-Anadouli, and F. M. El-Nizamy, "The effect of thiourea on the corrosion kinetics of mild steel in $\mathrm{H}_{2} \mathrm{SO}_{4}$," Corrosion Science, vol. 24, no. 6, pp. 497-507, 1984.

[19] B. G. Ateya, B. E. El-Anadouli, and F. M. El-Nizamy, "The adsorption of thiourea on mild steel," Corrosion Science, vol. 24, no. 6, pp. 509-515, 1984.

[20] J. D. Talati, M. N. Desai, and N. K. Shah, "Meta-Substituted aniline-N-salicylidenes as corrosion inhibitors of zinc in sulphuric acid," Materials Chemistry and Physics, vol. 93, no. 1, pp. 54-64, 2005.

[21] A. S. Fouda, M. N. Mousa, F. I. Taha, and A. I. Elneamaa, "The role of some thiosemicarbazide derivatives in the corrosion inhibition of aluminum in HCl," Corrosion Science, vol. 26, no. 9, pp. 719-729, 1986.

[22] A. S. Fouda, A. Abd El-Aal, and A. B. Kandil, "The effect of some phthalimide derivatives on the corrosion behaviour of copper in nitric acid," Anti-Corrosion Methods and Materials, vol. 52, no. 2, pp. 96-101, 2005. 

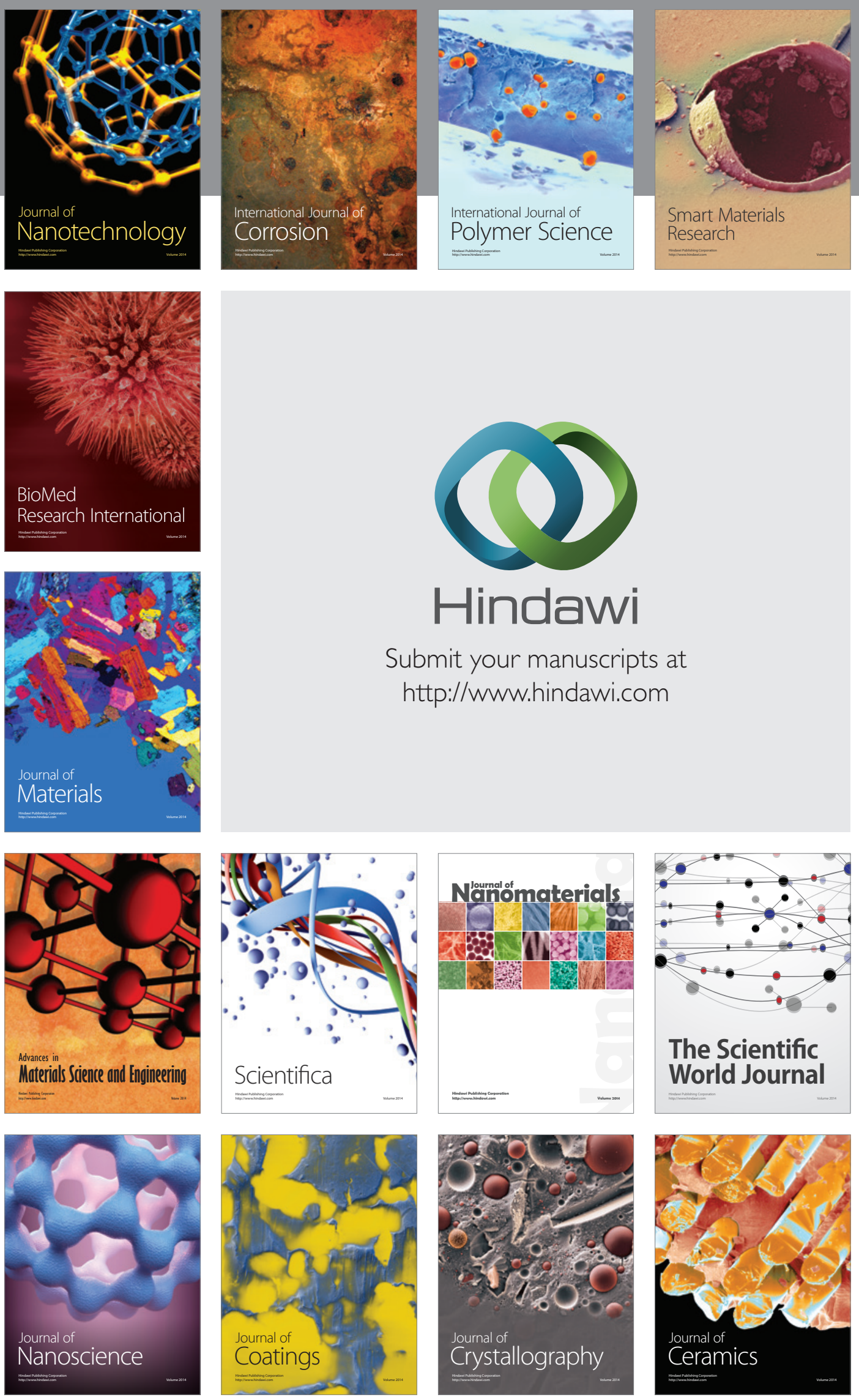

The Scientific World Journal

Submit your manuscripts at

http://www.hindawi.com

\section{World Journal}

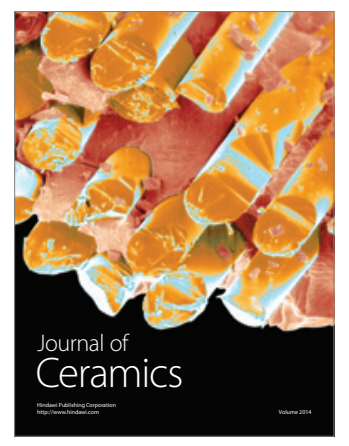

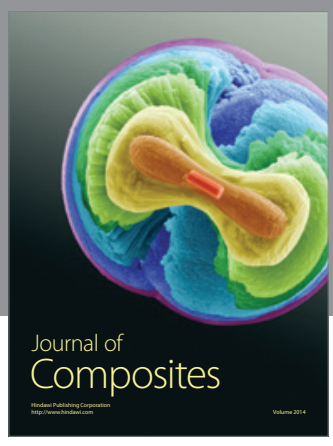
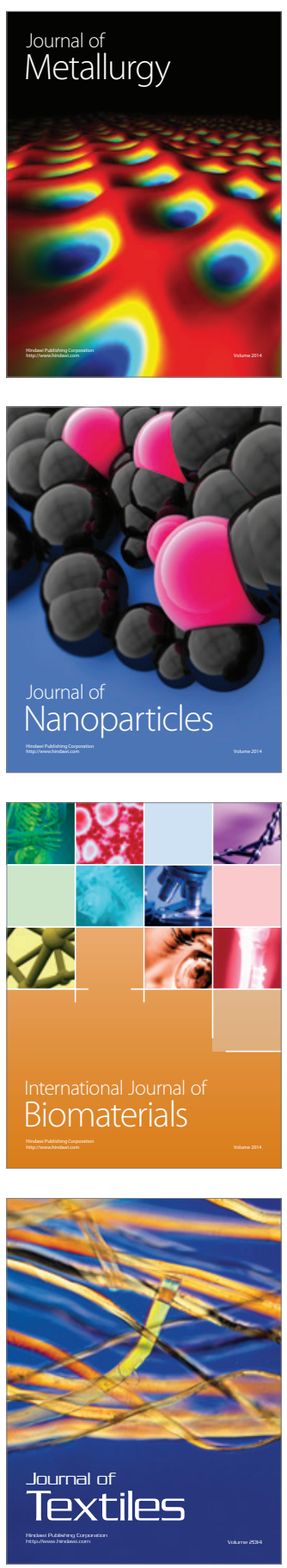